\title{
CSTX-1, a toxin from the venom of the hunting spider \\ Cupiennius salei, is a selective blocker of L-type calcium
} channels in mammalian neurons

\author{
${ }^{*}, 1$ Helmut Kubista, ${ }^{2}$ Roberta A. Mafra, ${ }^{3}$ Youmie Chong, ${ }^{3}$ Graham M. \\ Nicholson, ${ }^{2}$ Paulo S.L. Beirão, ${ }^{2}$ Jader S. Cruz, ${ }^{4}$ Stefan Boehm, ${ }^{5}$ Wolfgang \\ Nentwig \& ${ }^{5}$ Lucia Kuhn-Nentwig
}

${ }^{1}$ Center for Biomolecular Medicine and Pharmacology, Institute of Pharmacology, Medical University of Vienna, Waehringerstrasse 13a, A-1090, Vienna, Austria

${ }^{2}$ Department of Biochemistry and Immunology, Instituto de Ciências Biológicas, Universidade Federal de Minas Gerais, Av. Antonio Carlos 6627, 31270-901 Belo Horizonte, MG, Brazil

${ }^{3}$ Neurotoxin Research Group, Department of Medical \& Molecular Biosciences, University of Technology, Sydney, City Campus, Broadway, Sydney, NSW 2007, Australia

${ }^{4}$ Institute of Experimental and Clinical Pharmacology, Medical University of Graz, Universitätsplatz 4, A-8010 Graz, Austria

${ }^{5}$ Zoological Institute, University of Bern, Baltzerstrasse 6, CH-3012 Bern, Switzerland

*Author for correspondence: Telephone: ++43 1427764146

Fax: ++ 43142779641

E-mail: helmut.kubista@meduniwien.ac.at 


\section{Abstract}

The inhibitor cystine-knot motif identified in the structure of CSTX-1 from Cupiennius salei venom suggests that this toxin may act as a blocker of ion channels. Whole-cell patch clamp experiments performed on cockroach neurons revealed that CSTX-1 produced a slow voltageindependent block of both mid/low- (M-LVA) and high-voltage-activated (HVA) insect $\mathrm{Ca}_{\mathrm{v}}$ channels. Since Cupiennius salei venom affects both insect as well as rodent species, we investigated whether $\mathrm{Ca}_{\mathrm{v}}$ channel currents of rat neurons are also inhibited by CSTX-1. CSTX-1 blocked rat neuronal L-type, but no other types of $\mathrm{HVA} \mathrm{Ca}_{\mathrm{v}}$ channels, and failed to modulate LVA $\mathrm{Ca}_{\mathrm{v}}$ channel currents. Using neuroendocrine GH3 and GH4 cells, CSTX-1 produced a rapid voltage-independent block of L-type $\mathrm{Ca}_{\mathrm{v}}$ channel currents. The concentration-response curve was biphasic in GH4 neurons and the subnanomolar $I C_{50}$ values were at least 1000 -fold lower than in GH3 cells. L-type $\mathrm{Ca}_{\mathrm{v}}$ channel currents of skeletal muscle myoballs and other voltage-gated ion currents of rat neurons, such as $I_{\mathrm{Na}(\mathrm{V})}$ or $I_{\mathrm{K}(\mathrm{V})}$ were not affected by CSTX-1. The high potency and selectivity of CSTX-1 for a subset of Ltype channels in mammalian neurons may enable the toxin to be used as a molecular tool for the investigation of this family of $\mathrm{Ca}_{\mathrm{v}}$ channels.

Running Title: CSTX-1, a selective $\mathrm{Ca}_{\mathrm{v}}$ channel blocker

Keywords: Cupiennius salei venom; CSTX-1; voltage-gated calcium channels; DUM neurons; rat neurons

Abbreviations: ATP, adenosine-5'-triphosphate; $\mathrm{B}_{\max }$, maximum binding capacity; $\mathrm{Ca}_{\mathrm{v}}$ channel, voltage-gated $\mathrm{Ca}^{2+}$ channel; CSTX, peptide toxin from the venom of Cupiennius 
salei; DMEM, Dulbecco's-modified Eagles Media; DRG, dorsal root ganglion; DUM, dorsal unpaired median; EDTA, ethylenediaminetetraacetic acid: EGTA, ethylene glycol-bis ( $\beta$ aminoethylether)-N,N,N',N'-tetraacetic acid; ESI-MS, electrospray ionisation-mass spectrometry; GTP, guanosine-5'-triphosphate; HVA, high-voltage-activated; $I C_{50}$, median inhibitory concentration; ICK, inhibitor cystine-knot; $I_{\mathrm{Ca}(\mathrm{V})}$, voltage-gated calcium channel current; $I_{\mathrm{K}(\mathrm{V})}$, voltage-gated potassium channel current; $I_{\mathrm{Na}(\mathrm{V})}$, voltage-gated sodium channel current; $I-V$ curve, current-voltage relation curve; $\mathrm{K}_{\mathrm{v}}$ channel, voltage-gated $\mathrm{K}^{+}$channel; $L D_{50}$, median lethal dose; LVA, low-voltage-activated; M-LVA, mid/low-voltage-activated; $\mathrm{Na}_{\mathrm{v}}$ channel, voltage-gated $\mathrm{Na}^{+}$channel; PBS, phosphate-buffered saline; $\mathrm{r}^{2}$, regression coefficient; RP-HPLC, reverse phase high-pressure liquid chromatography; SCG, superior cervical ganglion; TAG, terminal abdominal ganglia; TEA, tetraethylammonium; HEPES, $N$ 2-hydroxyethylpiperazine- $N$ '-2-ethanesulfonic acid; TFA, trifluoroacetic acid; TTX, tetrodotoxin; $V_{\mathrm{h}}$, holding potential.

\section{Introduction}

A multitude of applications make venom toxins important molecular tools. Cell biologists are employing a variety of animal, plant and microbial toxins to investigate the contribution of their molecular targets to various cell functions and as lead compounds for the development of pesticides and therapeutics (Bailey and Wilce, 2001). For example, phyla-specific spider neurotoxins that interact selectively with insect membrane proteins are being examined for their potential as biopesticides (Tedford et al., 2004a, b). More recently, the pharmaceutical industry has discovered the pre-optimised combinatorial peptide library that animal venoms represent, and are searching for toxins as templates for drug design or directly as therapeutics (Harvey, 2002; Bogin, 2005). 
In neurobiology, specific antagonists are required to study the structure and role of voltage- and transmitter-gated ion channels. Venoms of different animals provide a rich but, as yet, largely unexplored source of ion channel modulators. Many of the toxins studied to date are selective blockers and discriminate between closely related ion channel subtypes. Families of $\mathrm{Ca}_{\mathrm{v}}$ channels have been identified pharmacologically using specific peptide toxins from marine cone snail and spider venoms (Doering and Zamponi, 2003). However, at present, many of the $\mathrm{Ca}_{\mathrm{v}}$ channel subtypes identified using molecular biology techniques cannot be isolated pharmacologically. This holds true for the L-type $\left(\mathrm{Ca}_{\mathrm{v}} 1 . \mathrm{x}\right)$ family of $\mathrm{Ca}_{\mathrm{v}}$ channels, which, for mammalian neurons, are characterised by their sensitivity to dihydropyridines. The differences in the affinity of dihydropyridines for the four L-type $\mathrm{Ca}_{\mathrm{v}}$ channel subtypes $\left(\mathrm{Ca}_{\mathrm{v}} 1.1\right.$ to 1.4$)$, identified to date, were found to be too small to permit the study of the functional role of these channels in various cell types (Bourinet et al., 2004). It is therefore valuable to further isolate and characterise venom components in a search for novel toxins that may be used as pharmacological tools to further dissect the structure and function of $\mathrm{Ca}_{\mathrm{v}}$ channels.

Cupiennius salei (Araneae: Ctenidae) is a nocturnal hunting spider inhabiting tropical rain forests from Central Mexico to northern South America (Kuhn-Nentwig et al., 2004). The venom of this spider is a complex mixture containing ions $\left(\mathrm{Na}^{+} 8.9 \mathrm{mM}, \mathrm{K}^{+} 215 \mathrm{mM}\right.$, and $\mathrm{Ca}^{2+} 0.94 \mathrm{mM}$ ), low molecular mass substances as amino acids (mainly glycine $43.3 \mathrm{pmol} / \mu 1$ and taurine $70.0 \mathrm{pmol} / \mu \mathrm{l}$ ), amines (histamine $5.7 \mathrm{nmol} / \mu \mathrm{l}$ ) and polyamines in low quantities (Kuhn-Nentwig et al., 1994, 2004). Beside proteins $\left(\mathrm{M}_{\mathrm{r}} 25-27 \mathrm{kDa}\right)$ such as the enzyme hyaluronidase, peptides in the molecular range between 3-4 $\mathrm{kDa}$ were identified and therein two peptide families were named cupiennin 1 and cupiennin 2 (Kuhn-Nentwig et al., 2004). These cationic cupiennins exhibit a toxic activity towards insects, a strong cytolytic activity to erythrocytes and are bactericidal in the submicromolar range towards Gram positive as well as Gram negative bacteria (Kuhn-Nentwig et al., 2002). Synergistic toxic effects were 
demonstrated between cupiennin 1a and the toxic peptides CSTX-1, 9 and CSTX-13 in a Drosophila bioassay (Wullschleger et al., 2005). Additionally, cupiennin 1a inhibits the formation of NO from neuronal nitric oxide synthase by involving complexation with the regulatory protein calcium calmodulin (Pukala et al., 2007). Most significant, though, are several neurotoxic peptides (CSTX), with molecular masses between 6 and $8 \mathrm{kDa}$, which are mainly responsible for the lethality of the venom. Interestingly, bioassays revealed that mice, despite not being usual prey species, are the most sensitive species to Cupiennius salei venom when compared to a wide range of arthropods (Kuhn-Nentwig et al., 1998). Among the 13 peptide toxins identified in C. salei venom (CSTX-1 to -13), the 74-residue peptide CSTX-1 is the most abundant and displays the highest toxicity in mammalian and insect bioassays (Kuhn-Nentwig et al., 1994). Despite the comprehensive knowledge of venom composition and peptide structure acquired within the last decade (Kuhn-Nentwig et al., 2004), evidence for the molecular targets of Cupiennius salei toxins remains obscure. CSTX-1, CSTX-9 and CSTX-13 are characterized by four disulfide bridges. Three of the four disulfide bridges form linkages between $\mathrm{C} 1-\mathrm{C} 4, \mathrm{C} 2-\mathrm{C} 5$ and $\mathrm{C} 3-\mathrm{C} 8$ and conform to an 'inhibitor cystine -knot' (ICK) motif (Norton and Pallaghy, 1998). This motif is characteristic for many ion channel blocking peptide toxins (Mouhat et al., 2004), especially from spider venoms (Nicholson, 2006). In this study we therefore tested the hypothesis that CSTX-1 may act as an antagonist of neuronal ion channels. We show that CSTX-1 blocks voltage-gated calcium $\left(\mathrm{Ca}_{\mathrm{v}}\right)$ channel currents in neurons of the cockroach Periplaneta americana, but does not appear to discriminate between mid/low- (M-LVA) and high-voltage-activated (HVA) $\mathrm{Ca}_{\mathrm{v}}$ channels. In rat neurons, CSTX-1 leaves LVA $\mathrm{Ca}_{\mathrm{v}}$ channel currents unaffected but acts as a selective blocker of dihydropyridine-sensitive L-type $\mathrm{HVA} \mathrm{Ca}_{\mathrm{v}}$ channels. The potency of block appears to depend on the subtype of L-type $\mathrm{Ca}_{\mathrm{v}}$ channels expressed in these neurons. Our data suggest that CSTX-1 has evolved as a blocker of insect $\mathrm{Ca}_{\mathrm{v}}$ channels, and has a structure that permits a high affinity interaction with a subtype of L-type $\mathrm{Ca}_{\mathrm{v}}$ channels expressed in mammalian 
neurons. CSTX-1 may thus have a potential as a research tool to investigate the physiological role of L-type $\mathrm{Ca}_{\mathrm{v}}$ channel subtypes. Some of these results have recently been presented in abstract form (Kubista et al., 2006).

\section{Materials and methods}

\subsection{Toxin isolation}

Spider maintenance, venom collection and purification of CSTX-1 were carried out as previously described (Kuhn-Nentwig et al., 1994) with the following modifications. Cation exchange liquid chromatography was performed on an Mono S HR 10/10 (10 cm x $1 \mathrm{~cm}$, Pharmacia, Sweden) at a flow rate of $0.5 \mathrm{ml} / \mathrm{min}$ using a $200 \mathrm{mM}$ ammonium acetate buffer, pH 5.5 and a gradient (B) of $200 \mathrm{mM}$ ammonium acetate and $2 \mathrm{M} \mathrm{NaCl}, \mathrm{pH}$ 5.5. The separation profile was $0 \%$ B for 20 min followed by a linear gradient from 0 to $100 \%$ from 20 to $74 \mathrm{~min}$. The fraction containing CSTX-1, which eluted at $1 \mathrm{M} \mathrm{NaCl}(50 \% \mathrm{~B})$, was desalted and separated by RP-HPLC using a Nucleosil 300-5 $\mathrm{C}_{4}$ column $(4.6 \mathrm{~mm}$ x $250 \mathrm{~mm}$, Macherey \& Nagel, Germany) with $0.1 \% \mathrm{v} / \mathrm{v}$ trifluoroacetic acid (TFA) in water for 0 to 15 min followed by a linear gradient of $0.1 \%$ TFA in acetonitrile from 0 to $10 \%$ from 15 to 30 min and from 10 to $50 \%$ from 30 to $125 \mathrm{~min}$. Rechromatography of the peptide was performed on the same column using isocratic conditions with $32 \%$ acetonitrile in TFA for 30 minutes. Starting with $1.8 \mathrm{ml}$ of crude venom we obtained $15 \mathrm{mg}$ of highly purified CSTX-1, by a combination of gel filtration, cationic exchange chromatography and successive RPHPLC. The purity of CSTX-1 was confirmed by RP-HPLC (Fig. 1), N-terminal amino acid sequencing, amino acid composition and electrospray ionisation-mass spectrometry (ESIMS). 


\subsection{DUM neurons}

Dorsal unpaired median (DUM) neurons from the terminal abdominal ganglion (TAG) of the nerve cord of the adult American cockroach, Periplaneta americana were isolated using methods modified from Grolleau and Lapied (1996) and Sinakevitch et al. (1996). Briefly, the sixth abdominal ganglia were excised, desheathed and incubated for $15 \mathrm{~min}$ at $37^{\circ} \mathrm{C}$ in insect saline of the following composition (in $\mathrm{mM}$ ): $200 \mathrm{NaCl}, 3.1 \mathrm{KCl}, 5 \mathrm{CaCl}_{2}, 4 \mathrm{MgCl}_{2}, 10 \mathrm{~N}-2$ hydroxyethylpiperazine- $N$ '-2-ethanesulfonic acid (HEPES), 40 D-glucose supplemented with $5 \% \mathrm{v} / \mathrm{v}$ foetal calf serum and $50 \mathrm{IU} / 1$ penicillin and streptomycin at $\mathrm{pH} 7.4$, containing 1 $\mathrm{mg} / \mathrm{ml}$ of collagenase and hyaluronidase. After washing in enzyme-free insect saline, DUM neurons were mechanically isolated from exogenous tissue by trituration, carefully passing the ganglia in and out of a sterile Pasteur pipette. The resulting suspension was then distributed into 8 wells of a 24-well cluster plate (Limbro, Ohio, USA). Each well contained a 12-mm diameter glass coverslip (Lomb Scientific, Taren Point, NSW, Australia), which had been previously coated with BD Cell-Tak ${ }^{\mathrm{TM}}$ (BD Biosciences, North Ryde, Sydney, Australia). Isolated cells were allowed to attach to the coverslips overnight in an incubator $\left(5 \% \mathrm{CO}_{2}, 95 \% \mathrm{O}_{2}, 100 \%\right.$ relative humidity, $\left.28^{\circ} \mathrm{C}\right)$ in normal insect saline supplemented with $5 \% \mathrm{v} / \mathrm{v}$ foetal calf serum, prior to experimentation.

\subsection{Rat SCG and DRG neurons}

Primary cultures of dissociated superior cervical ganglia (SCG) and dorsal root ganglia (DRG) neurons from neonatal rats were prepared as described previously (Lechner et al., 2003). Briefly, ganglia were dissected from 2 to 6 day-old Sprague Dawley rat pups that had been killed by decapitation in accordance with the rules of the Animal Welfare Committee of 
the Medical University of Vienna. Ganglia were cut into 3 to 4 pieces and incubated in 1.5 $\mathrm{mg} / \mathrm{ml}$ collagenase and $3.0 \mathrm{mg} / \mathrm{ml}$ dispase (Sigma, Vienna, Austria) for $20 \mathrm{~min}$ at $36^{\circ} \mathrm{C}$. Subsequently, they were trypsinised $(2.5 \mathrm{mg} / \mathrm{ml}$ trypsin; Worthington, Lakewood, NJ, USA) for $15 \mathrm{~min}$ at $36^{\circ} \mathrm{C}$, dissociated by trituration, and resuspended in Dulbecco's-modified Eagle's Medium (DMEM; Invitrogen, Lofer, Austria) containing 2.2 g/l D-glucose, 10 mg/1 insulin, $50.000 \mathrm{IU} / 1$ penicillin and $50 \mathrm{mg} / \mathrm{l}$ streptomycin (Invitrogen, Lofer, Austria), $50 \mu \mathrm{g} / \mathrm{l}$ nerve growth factor (Invitrogen, Lofer, Austria), and 5\% v/v foetal calf serum (Invitrogen, Lofer, Austria). Thereafter, the cells were plated onto $35 \mathrm{~mm}$ diameter culture dishes, previously coated with rat tail collagen, for electrophysiological experiments. DRG neurons were used on the day of plating, whereas SCG neurons were used for recordings within one week following plating. During that period SCG neurons were maintained in a humidified 5\% $\mathrm{CO}_{2}$ atmosphere at $37^{\circ} \mathrm{C}$. Media were exchanged on day one after plating and after another 4 to 5 days.

\subsection{Cell lines}

GH3 cells (American Type Culture Collection, Manassas, USA) were cultured in DMEMHEPES modification (Sigma, USA) supplemented with 10\% v/v foetal calf serum (Cultilab, Brazil). The cells were routinely grown as stocks in $75 \mathrm{~cm}^{2}$ flasks (Costar, USA) at $37^{\circ} \mathrm{C}$ in a humidified $5 \% \mathrm{CO}_{2}$ atmosphere. The medium was changed three times a week. For electrophysiological recordings the cells were detached by trypsinisation, subcultured on glass coverslips (Corning \#1, USA) without any pretreatment and plated in $47 \mathrm{~mm}$ diameter dishes. Trypsinisation was carried out with $0.1 \% \mathrm{w} / \mathrm{v}$ trypsin in the culture medium without serum and with $1 \mathrm{mM}$ EDTA. Cells were used for electrophysiological recordings 1-2 days after plating. 
GH4 cells (provided by T. Weiger, University of Salzburg, Austria) were grown in Nutrient Mixture F-10 Ham media supplemented with 15\% v/v horse serum, 2.5\% v/v foetal calf serum, $50.000 \mathrm{IU} / 1$ penicillin, $50 \mathrm{mg} / \mathrm{l}$ streptomycin and $2 \mathrm{mM}$ L-glutamine. The cells were routinely grown as stocks in $10 \mathrm{~cm}$ diameter dishes (Iwaki, Japan) at $37^{\circ} \mathrm{C}$ in a humidified $5 \% \mathrm{CO}_{2}$ atmosphere. Cells were split once a week and growth media were replaced once between passages. For patch clamp experiments, GH4 cells were detached by trypsinisation and seeded at low density on poly-D-lysine-coated $35 \mathrm{~mm}$ diameter dishes.

Cell culture and differentiation of the $\mathrm{C} 3 \mathrm{H}$ murine skeletal $\mathrm{C} 2 \mathrm{C} 12$ cell line was carried out as described elsewhere (Zebedin et al., 2004). Briefly, cultures were maintained in serum containing $20 \% \mathrm{v} / \mathrm{v}$ fetal calf serum and differentiation of myoblasts was induced by serum reduction $(2 \% \mathrm{v} / \mathrm{v}$ horse serum instead of $20 \% \mathrm{v} / \mathrm{v}$ fetal calf serum $)$ on cells plated onto Matrigel. Electrophysiological experiments were performed 14 days after induction of differentiation on C2C12 myoballs as described previously (Zebedin et al., 2004).

\subsection{Electrophysiology}

Whole cell voltage-clamp recordings were performed at room temperature $\left(20-24^{\circ} \mathrm{C}\right)$ using borosilicate glass patch pipettes of 2-3.5 $\mathrm{M} \Omega$ tip resistance when filled with internal solution (see below) and patch clamp amplifiers from Axon Instruments (Axon Instruments, Foster City, CA, USA) or HEKA (HEKA Elektronik, Germany). Currents were elicited by voltage steps from a holding potential $\left(V_{\mathrm{h}}\right)$ of $-80 \mathrm{mV}$ in $\mathrm{GH} 3$ and $\mathrm{GH} 4$ cells, $\mathrm{C} 2 \mathrm{C} 12$ myoballs and SCG neurons, from $-100 \mathrm{mV}$ in DRG neurons, and from $-90 \mathrm{mV}$ in DUM neurons, to the indicated depolarised potentials. Voltage steps were in most cases applied every $15 \mathrm{~s}$, but pulse frequency was increased up to every $5 \mathrm{~s}$ in some experiments for a better resolution of the kinetics of current inhibition. Leakage and capacitive currents were digitally 
subtracted on-line with $P-P / 4$ procedures. Data were low-pass filtered at 2 to $5 \mathrm{kHz}$, digitised at 10 to $50 \mathrm{kHz}$ and stored on computer for subsequent off-line analysis.

In whole-cell voltage-clamp recordings from DUM neurons, $I_{\mathrm{Ba}}$ were recorded using an Axopatch 200A patch-clamp amplifier and AxoData v3.0 software (Axon Instruments). Patch pipettes were filled with an internal solution of the following composition (in $\mathrm{mM}$ ): 50 choline-Cl, $30 \mathrm{CsCl}$, 50 TEA-Br, $2 \mathrm{Na}_{2}-\mathrm{ATP}, 0.5 \mathrm{CaCl}_{2}$, 10 ethylene glycol-bis ( $\beta$ aminoethylether)-N,N,N',N'-tetraacetic acid (EGTA), 10 HEPES and adjusted to pH 7.25 using $\mathrm{CsOH}$. The external solution for recording $I_{\mathrm{Ba}}$ in DUM neurons contained (in $\mathrm{mM}$ ): 160 choline-Cl, 50 TEA-Br, $3 \mathrm{BaCl}_{2}, 10$ HEPES, $500 \mathrm{nM}$ tetrodotoxin (TTX), and the $\mathrm{pH}$ was adjusted to 7.4 using TEA-OH. $500 \mu \mathrm{M} \mathrm{Cd}^{2+}$, a known insect $\mathrm{Ca}_{\mathrm{v}}$ channel blocker, was used to abolish peak inward $I_{\mathrm{Ba}}$, and confirmed the currents recorded were carried through this channel. Toxins and drugs were applied via a pressurised fast perfusion system (AutoMate Scientific, San Francisco CA, USA).

In whole-cell voltage-clamp recordings from GH3 cells, $I_{\mathrm{Ba}}$ were recorded using a HEKA EPC-9 patch-clamp amplifier. The internal pipette solution was of the following composition (in mM): $130 \mathrm{CsCl}, 10$ TEA-Cl, 2 Mg-ATP, 0.1 Li-GTP, 5 EGTA, 5 HEPES, and adjusted to $\mathrm{pH} 7.2$ using $\mathrm{CsOH}$. The cells were perfused continuously with an external solution containing (in $\mathrm{mM}$ ): $140 \mathrm{NaCl}, 25 \mathrm{BaCl}_{2}, 0.5 \mathrm{MgCl}_{2}, 5 \mathrm{CsCl}, 5 \mathrm{HEPES}, 0.1 \mu \mathrm{M}$ TTX, and adjusted to $\mathrm{pH} 7.4$ using $\mathrm{NaOH}$.

Whole-cell ionic currents from SCG neurons, DRG neurons, GH4 cells and C2C12 myoballs were recorded as described previously (Vartian and Boehm, 2001), using an Axopatch 200B amplifier and pCLAMP v8.0 software. The internal pipette solution consisted of (in mM): (A) $140 \mathrm{KCl}, 1.59 \mathrm{CaCl}_{2}, 10 \mathrm{HEPES}, 10$ EGTA, $2 \mathrm{Mg}$-ATP, 2 Li-GTP, adjusted to $\mathrm{pH} 7.2$ with $\mathrm{KOH}$ for measurement of outward $I_{\mathrm{K}(\mathrm{V})}$, or (B) $130 \mathrm{CsCl}, 20$ tetraethylammonium (TEA)-Cl, $0.24 \mathrm{CaCl}_{2}, 10$ D-glucose, 10 HEPES, 5 EGTA, 2 Mg-ATP, and 2 Li-GTP, adjusted to $\mathrm{pH} 7.2$ with $\mathrm{CsOH}$, for measurement of $I_{\mathrm{Ba}}$ and $I_{\mathrm{Na}(\mathrm{V})}$ currents, 
respectively. The external bathing solution contained (in $\mathrm{mM}$ ): (A) $120 \mathrm{NaCl}, 3 \mathrm{KCl}, 2$ $\mathrm{MgCl}_{2}, 2 \mathrm{CaCl}_{2}, 20$ D-glucose, 10 HEPES, adjusted to $\mathrm{pH} 7.4$ with $\mathrm{NaOH}$ for the measurement of outward $I_{\mathrm{K}(\mathrm{V})}$, or $(\mathrm{B}) 120 \mathrm{NaCl}, 3 \mathrm{KCl}, 2 \mathrm{MgCl}_{2}, 5 \mathrm{CaCl}_{2}\left(I_{\mathrm{Na}(\mathrm{V})}\right)$ or $5 \mathrm{BaCl}_{2}$ $\left(I_{\mathrm{Ba}}\right), 20$ TEA-Cl, 20 D-glucose, 10 HEPES, adjusted to $\mathrm{pH} 7.4$ with $\mathrm{NaOH}$ for the measurement of high-voltage activated $I_{\mathrm{Ba}}$ and $I_{\mathrm{Na}(\mathrm{V})}$. In addition, TTX $(0.5 \mu \mathrm{M})$ or $\mathrm{CdCl}_{2}(0.5$ $\mathrm{mM}$ ) were added to the external solution to isolate either high-voltage activated $I_{\mathrm{Ba}}$ or $I_{\mathrm{Na}(\mathrm{V})}$ currents, respectively. For the measurement of $\mathrm{LVA} \mathrm{Ca}_{\mathrm{v}}$ channel currents in DRG neurons, TTX-sensitive and -insensitive $I_{\mathrm{Na}(\mathrm{V})}$ were eliminated by replacement of $\mathrm{NaCl}$ with choline-Cl using the following bathing solution (in $\mathrm{mM}$ ): 120 choline- $\mathrm{Cl}, 3 \mathrm{KCl}, 2 \mathrm{MgCl}_{2}, 5 \mathrm{BaCl}_{2}, 20$ TEA-Cl, 20 D-glucose, 10 HEPES, adjusted to $\mathrm{pH} 7.4$ with $\mathrm{CsOH}$. Drugs and toxins were applied via a DAD-12 drug application device (Adams \& List, Westbury, NY, USA).

\subsection{Data Analysis}

Traces were analysed off-line using Clampfit or AxoGraph v4.0 (Axon Instruments) or PulseFit (HEKA). Mathematical curve fitting employed algorithms available in ORIGIN v5.0 software (Microcal Software, Northampton, MA), Sigma Plot v5.0 (SPSS Inc., Richmond, CA) or GraphPad Prism v4.0 for Macintosh (GraphPad Software, San Diego CA, USA) using non-linear least-squares methods. Concentration-response curves in GH3 and DUM neurons were fitted using the following form of the Langmuir equation:

$$
y=B_{\max } \cdot \frac{[C]}{I C_{50}+[C]}
$$

(Equation 1)

where $y$ is the percentage current inhibition, $B_{\max }$ is the maximum response (typically 100), $[C]$ is the toxin concentration, and $I C_{50}$ is the concentration at half-maximal block. 
Concentration-response curves in GH4 cells were fitted using a two-site binding model using the following equation:

$$
y=B_{\max 1} \cdot \frac{[C]}{I C_{50(1)}+[C]}+B_{\max 2} \cdot \frac{[C]}{I C_{50(2)}+[C]}
$$

Current-voltage $(I-V)$ curves were fitted using the following equation:

$$
I=g_{\max }\left(1-\left(\frac{1}{1+\exp \left[\left(V-V_{1 / 2}\right) / s\right]}\right)\right)\left(V-V_{\text {rev }}\right) \quad \text { (Equation 3) }
$$

where $I$ is the amplitude of the peak current at a given test potential $V, g_{\max }$ is the maximal conductance, $V_{1 / 2}$ is the voltage at half-maximal activation, $s$ is the slope factor, and $V_{\text {rev }}$ is the apparent reversal potential.

\subsection{Chemicals}

ATP-Mg, GTP-Li, TEA-Cl, Nutrient Mixture F-10 Ham, poly-D-lysine, nitrendipine, nicardipine hydrochloride and bulk chemicals were from Sigma (Vienna, Austria or St. Louis, USA). Unless otherwise stated all sera and antibiotics were from Life Technologies (Vienna, Austria). Matrigel was obtained from Becton Dickinson (Schwechat, Austria), rat tail collagen was from Biomedical Technologies (Stoughton, MA), TTX was purchased from Latoxan (Valence, France), and w-conotoxin GVIA was obtained from Alomone Labs (Jerusalem, Israel). 


\section{Results}

\subsection{Effects of CSTX-1 on insect neurons}

To test the hypothesis that ion channel antagonism may underlie the toxicity of CSTX-1 in typical prey animals of Cupiennius salei we investigated the blocking effect of CSTX-1 on insect $\mathrm{Ca}_{\mathrm{v}}$ channels in DUM neurons of the cockroach Periplaneta americana. We focused our attention on two subtypes of $\mathrm{Ca}_{\mathrm{v}}$ channels that are activated by suprathreshold voltages: a mid- to low- (M-LVA) and a high-voltage-activated (HVA) $\mathrm{Ca}_{\mathrm{v}}$ channel (Wicher and Penzlin, 1994, 1997). To prevent $\mathrm{Ca}^{2+}$-induced rundown of $\mathrm{Ca}^{2+}$ currents, $\mathrm{Ba}^{2+}$ was used as a charge carrier instead of $\mathrm{Ca}^{2+}$ (Wicher and Penzlin, 1997). Macroscopic $I_{\mathrm{Ba}}$ through $\mathrm{Ca}_{\mathrm{v}}$ channels were elicited by 100-ms depolarising command pulses from a $V_{\mathrm{h}}$ of $-90 \mathrm{mV}$. Inward $I_{\mathrm{Ba}}$ were evoked by depolarising pulses to $-30 \mathrm{mV}$ (M-LVA Ca $\mathrm{v}_{\mathrm{v}}$ channel currents dominating) and +30 $\mathrm{mV}$ (HVA $\mathrm{Ca}_{\mathrm{v}}$ channel currents dominating). Depolarisations to $-30 \mathrm{mV}$ (Fig. 2A, C, E) caused a large inward current with slow decaying component, whereas depolarisations to +30 $\mathrm{mV}$ elicited a smaller current with a fast decaying component (Fig. 2B, D, F). The addition of $300 \mathrm{nM}$ CSTX-1 resulted in a block of peak $I_{\mathrm{Ba}}$ of $34.2 \pm 4 \%(n=5)$ within 5 minutes at -30 $\mathrm{mV}$ (Fig. 2A), and $44.2 \pm 2 \%$ block of peak $I_{\mathrm{Ba}}$ at depolarising pulses to $+30 \mathrm{mV}(\mathbf{n}=5)$ (Fig.

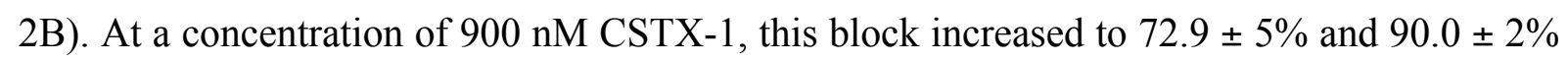
at $-30 \mathrm{mV}$ (Fig. 2C) and $+30 \mathrm{mV}$ (Fig. 2D) respectively $(n=4)$, with total block only being achieved at concentrations above $1 \mu \mathrm{M}$ CSTX-1. The time course of toxin-induced $I_{\mathrm{Ba}}$ inhibition was relatively slow and described by a single exponential function with $\tau_{\text {on }}$ of 33.1 s. In addition, the recovery after prolonged washout with toxin-free external solution was incomplete. By fitting the concentration-response curve of the inhibition of peak $I_{\mathrm{Ba}}$ using a Langmuir equation (Equation 1; see Methods), the concentration of CSTX-1 at half-maximal 
block $\left(I C_{50}\right)$ at a $-30 \mathrm{mV}$ depolarising pulse was determined to be $467 \mathrm{nM}$, and $274 \mathrm{nM}$ at +30 $\mathrm{mV}$ (Fig. 2G, H).

To determine if the block of $\mathrm{Ca}_{\mathrm{v}}$ channels by CSTX-1 was due to a depolarising shift in the voltage-dependence of channel activation, families of $I_{\mathrm{Ba}}$ were generated by 100 -ms test pulses from $V_{\mathrm{h}}(-90 \mathrm{mV})$ to a maximum of $+40 \mathrm{mV}$ in $10-\mathrm{mV}$ increments, every 10 seconds. Barium currents were recorded before (Fig. 3A), and after (Fig. 3B) perfusion with $300 \mathrm{nM}$ CSTX-1 (n=3). The $I_{\mathrm{Ba}}-V$ relationship was determined from the maximal $I_{\mathrm{Ba}}$ values at each potential (Fig. 3C). Data were normalised against peak maximal control $I_{\mathrm{Ba}}$ and fitted with Equation 3 (see Methods). No significant shift was observed in the voltage at half-maximal activation, $V_{1 / 2}$, or slope factor, $s$. In addition, CSTX-1 at concentrations of 100 and $300 \mathrm{nM}$ produced a voltage-independent block at all test potentials (Fig. 3D).

\subsection{Effects of CSTX-1 on barium currents in SCG neurons}

The experiments on cockroach DUM neurons indicated that CSTX-1 acts as a blocker of Ca channels. Since mice were found to be the most sensitive species to Cupiennius salei venom (Kuhn-Nentwig et al., 1998), we tested CSTX-1 on various $\mathrm{Ca}_{\mathrm{v}}$ channel currents of rodent neurons. Initially we investigated the effects of CSTX-1 on currents flowing through $\mathrm{Ca}_{\mathrm{v}}$ channels in primary cultures of rat SCG neurons, because these neurons express $\mathrm{Ca}_{\mathrm{v}}$ channels of the L-, N- and R-type families (Lin et al., 1996). To avoid $\mathrm{Ca}^{2+}$-dependent inactivation of $\mathrm{Ca}_{\mathrm{v}}$ channels and to prevent $\mathrm{Ca}^{2+}$-induced rundown of $\mathrm{Ca}^{2+}$ currents (Kepplinger et al., 2000; Soldatov, 2003), $\mathrm{Ba}^{2+}$ was substituted for $\mathrm{Ca}^{2+}$ as the charge carrier. $\mathrm{Ba}^{2+}$ currents were evoked by $30-\mathrm{ms}$ voltage steps from a holding potential of $-80 \mathrm{mV}$ to $0 \mathrm{mV}$. At a concentration of $1 \mu \mathrm{M}$ CSTX-1 inhibited, on average, $28.5 \pm 6.4 \%(n=11)$ of $I_{\mathrm{Ba}}$. An example of this effect is shown in Fig. 4A. To identify which subtype(s) of $\mathrm{Ca}_{\mathrm{v}}$ channels is affected by CSTX-1 we tested the additivity of CSTX-1 and blockers of L- and N-type Ca 
channels. When the L-type component of $I_{\mathrm{Ba}}$ was blocked by $1 \mu \mathrm{M}$ nitrendipine, CSTX-1 at 1 $\mu \mathrm{M}$ did not further reduce the current ( $n=4$, Fig. 4B). CSTX-1 did, however, block $I_{\mathrm{Ba}}$ when the N-type component was removed by $1 \mu \mathrm{M} \omega$-conotoxin GVIA $(n=3$, Fig. 4C, D). Our data indicate that CSTX-1 selectively blocks L-type $\mathrm{Ca}_{\mathrm{v}}$ channels in SCG neurons, whilst sparing other $\mathrm{Ca}_{\mathrm{v}}$ channel subtypes, for example N-type channels.

\subsection{Effects of CSTX-1 on barium currents in GH3 and GH4 cells}

To corroborate the finding that CSTX-1 may act as an inhibitor of L-type $\mathrm{Ca}_{\mathrm{v}}$ channels, we tested CSTX-1 on GH3 cells, because $I_{\mathrm{Ca}(\mathrm{V})}$ in these cells flows primarily via L-type $\mathrm{Ca}_{\mathrm{v}}$ channels (Lievano et al., 1994; Leão et al., 2000; Glassmeier et al., 2001; Safa et al., 2001). Barium currents were elicited in $\mathrm{GH} 3$ cells by 50 -ms voltage pulses to $0 \mathrm{mV}$ from a holding potential of $-80 \mathrm{mV}$. The dihydropyridine nicardipine $(4 \mu \mathrm{M})$ inhibited $I_{\mathrm{Ba}}$ by more than $90 \%$ (typically $95 \%, \mathbf{n}=$ ?, data not shown). CSTX-1 at a concentration of $1 \mu \mathrm{M}$ markedly and reversibly inhibited these currents $(\mathbf{n}=$ ?), as depicted in Figure 5A and B. The time course of inhibition could be described by a single exponential function with a time constant $\left(\tau_{\text {on }}\right)$ of 3.1 $\mathrm{s}$, indicating that the rate of inhibition is very rapid ( $\mathbf{n}=$ ?, Fig. 5C). CSTX-1 caused an inhibition of $I_{\mathrm{Ba}}$ that, at the holding potential $\left(V_{\mathrm{h}}=-80 \mathrm{mV}\right)$, was independent of the test potential ( $n=3$, Fig. 5D, E). To investigate the potency of CSTX-1 we tested the blocking effect at concentrations between 30 and $1000 \mathrm{nM}$. Inhibition was allowed to fully develop and amplitudes of inhibited currents were determined 30 to 60 seconds after toxin application Fig. 6A shows representative superimposed current traces obtained in the absence (control) and presence of $30 \mathrm{nM}$ and $300 \mathrm{nM}$ CSTX-1. The concentration-response graph determined from these experiments shows that CSTX-1 inhibits $I_{\mathrm{Ba}}$ in GH3 cells in a concentration-dependent manner ( $n=$ ? for each concentration) (Fig. 6B). At the highest toxin concentration tested, the inhibition of $I_{\mathrm{Ba}}$ amounted to $91.5 \pm 3.3 \%(n=5)$. The concentration-response data were fitted 
to a Langmuir isotherm, assuming a single-site inhibition model, and the parameters $B_{\max }$ and $I C_{50}$ were estimated using Equation 1 (see Methods). $B_{\max }$ was constrained to a maximum of $100 \%$ inhibition, and the best fit was obtained with an $I C_{50}$ value of $263 \mathrm{nM}$ (continuous line on Fig. $\left.6 \mathrm{~B}, \mathrm{r}^{2}=0.915\right)$. Little alteration occurred when $B_{\max }$ was constrained to $95 \%$, the typical percentage of nicardipine-sensitive $I_{\mathrm{Ba}}\left(I C_{50}=233 \mathrm{nM}, \mathrm{r}^{2}=0.900\right)$ or when the Hill coefficient (n) was treated as a variable $\left(I C_{50}=265 \mathrm{nM}, \mathrm{n}=1.09, \mathrm{r}^{2}=0.918\right)$. The data suggest that CSTX-1 can completely inhibit L-type $\mathrm{Ca}_{\mathrm{v}}$ channels. We performed similar experiments on GH4 cells, a clonal isolate of $\mathrm{GH} 3$, because these cells lack $\mathrm{Na}_{\mathrm{v}}$ channels and, in the presence of $\mathrm{K}_{\mathrm{v}}$ channel blockers, depolarising voltage steps evoke only inward currents via $\mathrm{Ca}_{\mathrm{v}}$ channels. In this cell line, $I_{\mathrm{Ba}}$ were also inhibited by CSTX-1 in a fully reversible (control current levels were restored at least within $30 \mathrm{~s}$ after toxin removal, data not shown) and concentration-dependent manner (Fig. 7A). Here, the apparent affinity of the toxin was considerably higher than in GH3 cells. Maximum current inhibition was observed at concentrations below $100 \mathrm{nM}$, because 30 and $100 \mathrm{nM}$ CSTX-1 blocked the same percentage of total $I_{\mathrm{Ba}}$ (namely $80.0 \pm 5.1 \%$, and $76.7 \pm 9.0 \%$, respectively). This is illustrated in the concentration-response curve shown in Fig. 7B ( $n=3$ to 5 for each concentration) and in the sample traces in Fig. 7C and 7D. The concentration-response data in Fig. 7B could be best fitted $\left(r^{2}=0.989\right)$ by employing a two-site binding model using Equation 2 (see Materials and Methods). With this fit, two plateaus with $B_{\max 1}=34.2 \%$ and $B_{\max 2}=45.2 \%$ with corresponding $\mathrm{IC}_{50}$ values of $I C_{50(1)}=0.03 \mathrm{pM}$ and $I C_{50(2)}=393 \mathrm{pM}$ were determined. To confirm that $I_{\mathrm{Ba}}$ was carried by L-type $\mathrm{Ca}_{\mathrm{v}}$ channels in the GH4 cells we performed experiments using the dihydropyridine $\mathrm{Ca}_{\mathrm{v}}$ channel antagonist nitrendipine. A concentrationresponse curve for the current block by nitrendipine was established to determine the contribution of the L-type $\mathrm{Ca}^{2+}$ current to $I_{\mathrm{Ba}}$ at a saturating concentration of the dihydropyridine. These experiments revealed an $I C_{50}$ for nitrendipine of $267 \mathrm{nM}$ and showed that on average $73.9 \pm 6.1 \%(n=5-9)$ of $I_{\mathrm{Ba}}$ in GH4 cells are carried via L-type $\mathrm{Ca}_{\mathrm{v}}$ channels 
(Fig. 8). This data also indicates clonal variation between GH3 and GH4 cells, since in the former cell line we observed up to a $95 \%$ contribution of the dihydropyridine-sensitive channel subtype to whole cell $\mathrm{Ca}^{2+}$ currents (see above).

\subsection{CSTX-1 does not affect T-type and muscle L-type Ca channels}

Having identified L-type $\mathrm{Ca}_{\mathrm{v}}$ channels as a high affinity target of CSTX-1, we aimed to further address the subtype selectivity of this toxin. Because $100 \mathrm{nM}$ CSTX-1 induced a saturating effect on $I_{\mathrm{Ba}}$ in GH4 cells and caused considerable inhibition in GH3 cells, we used this concentration to test for a specific effect of the spider toxin on other types of $\mathrm{Ca}_{\mathrm{v}}$ channels. Since the effect of CSTX-1 on L-type $\mathrm{Ca}_{\mathrm{v}}$ channels in GH3/GH4 cells was rapid, we evaluated current amplitudes after a $60 \mathrm{sec}$ toxin application period, a duration during which maximum inhibition had always been reached in the experiments on GH3 and GH4 cells.

Dihydropyridine-insensitive $I_{\mathrm{Ba}}$ in SCG neurons were not affected by CSTX-1. While this current was suggested to flow via N-, R- and P/Q-type $\mathrm{Ca}_{\mathrm{v}}$ channels (Lin et al., 1996), other types of $\mathrm{Ca}_{\mathrm{v}}$ channels are not present in this neuronal cell type and thus need to be investigated separately in other preparations. We used dorsal root ganglion (DRG) neurons to test CSTX-1 on T-type $\mathrm{Ca}_{\mathrm{v}}$ channels. Currents carried via these channels are characterized by their transient nature, low-voltage-activation (LVA channels) and by pronounced steady-state inactivation at depolarized potentials. When TTX-resistant $I_{\mathrm{Na}(\mathrm{V})}$ were eliminated by replacement of sodium chloride with choline chloride in the bathing solution, a population of $\mathrm{Ca}_{\mathrm{v}}$ channel currents that fitted these criteria were evoked in DRG neurons by voltage steps from a holding potential of $-100 \mathrm{mV}$ to a range of potentials between $-55 \mathrm{mV}$ and $-25 \mathrm{mV}$. Voltage steps to more depolarized potentials also evoked long-lasting $\mathrm{HVA} \mathrm{Ca}_{\mathrm{v}}$ channel currents (Fig. 9A, B and data not shown). We chose $-40 \mathrm{mV}$ as a suitable test potential to 
study the effect of CSTX-1 on isolated T-type $\mathrm{Ca}_{\mathrm{V}}$ channel currents, because at this potential LVA currents appear to be maximally activated and minimally contaminated by HVA $\mathrm{Ca}_{\mathrm{v}}$ channel currents. Following application of $100 \mathrm{nM}$ CSTX-1, T-type $\mathrm{Ca}_{\mathrm{v}}$ channel current amplitudes remained at 100.6 $\pm 10.0 \%(n=14$, Fig. 9C). Because CSTX-1 inhibited M-LVA $\mathrm{Ca}_{\mathrm{v}}$ channel currents in DUM neurons with comparably low affinity $\left(\mathrm{IC}_{50} 282 \mathrm{nM}\right.$, see section 3.1) we also tested $1 \mu \mathrm{M}$ CSTX-1 on the rat LVA Ca $a_{v}$ channel currents: however, T-type $\mathrm{Ca}_{\mathrm{v}}$ channel current amplitudes still remained unaffected and current amplitudes amounted to 96.1 $\pm 13.6 \%$ of control ( $n=7$, data not shown).

The data therefore demonstrate that CSTX-1 blocks vertebrate ion channels belonging to the L-type family of $\mathrm{Ca}_{\mathrm{v}}$ channels, whereas channels of the N-, R- and T-type families appear to be insensitive to CSTX-1. To test for subtype-selectivity within the L-type family of $\mathrm{Ca}_{\mathrm{v}}$ channels, we also addressed the question of whether $\mathrm{Ca}_{\mathrm{v}}$ channels in skeletal muscle cells, which belong to the $\mathrm{Ca}_{\mathrm{v}} 1.1$ subtype of the L-type $\mathrm{Ca}_{\mathrm{v}}$ channel family (Catterall et al., 2003), could be inhibited by CSTX-1. We evoked $I_{\mathrm{Ba}}$ in $\mathrm{C} 2 \mathrm{C} 12$ myoballs, using voltage-steps to +20 $\mathrm{mV}$ from a holding potential of $-80 \mathrm{mV}$. In these muscle cells, $I_{\mathrm{Ba}}$ remained largely unaltered by $100 \mathrm{nM} \mathrm{CSTX-1}$ with current amplitudes only decreased to $94.2 \pm 0.6 \%$ of control $(n=3)$. The overlay of current traces obtained before and after toxin application revealed that neither current kinetics nor the amplitude is significantly affected by 100 nM CSTX-1 (Fig.9D).

\subsection{CSTX-1 does not affect potassium and sodium currents}

To determine whether CSTX-1 affects ionic currents other than those flowing via $\mathrm{Ca}_{\mathrm{v}}$ channels, $I_{\mathrm{K}(\mathrm{V})}$ were evoked in GH4 cells by $150-\mathrm{ms}$ voltage steps from a $V_{\mathrm{h}}$ of $-80 \mathrm{mV}$ to $+120 \mathrm{mV}$. Application of $20 \mathrm{mM}$ TEA significantly reduced these outward currents. CSTX-1 did not alter the TEA-sensitive outward $I_{\mathrm{K}(\mathrm{V})}$. With 100 nM CSTX-1 outward currents remained at $99.1 \pm 2.5 \%$ (peak) and $99.4 \pm 3.4 \%$ (at the end of the 150 -ms voltage step, Fig. 
$10 \mathrm{~A}, n=5)$. For the investigation of $I_{\mathrm{Na}(\mathrm{V})}$ we used primary cultures of SCG neurons. Sodium currents were evoked by $30-\mathrm{ms}$ voltage steps from a holding potential of $-80 \mathrm{mV}$ to $-10 \mathrm{mV}$. In the presence of $100 \mathrm{nM}$ CSTX-1 $I_{\mathrm{Na}(\mathrm{V})}$ remained largely unaltered with peak currents measuring $105.5 \pm 8.6 \%$ of control $(n=5)$. These currents were, however, sensitive to TTX, which produced a complete block at a concentration of $0.5 \mu \mathrm{M}$ (Fig. 10B). Additionally, we tested $I_{\mathrm{Na}(\mathrm{V})}$ in GH3 cells for CSTX-1 sensitivity, but again observed no alterations of the currents upon toxin application (data not shown).

\section{Discussion}

CSTX-1 is the most important component of Cupiennius salei venom in terms of relative abundance and toxicity and therefore is likely to contribute significantly to the overall toxicity of the whole venom (Kuhn-Nentwig et al., 2004). The inhibitor cystine-knot structural motif identified for CSTX-1 indicated that this toxin may act as a modulator of voltage-gated ion channels. Moreover, the partial sequence homology with $\omega$-toxins from Phoneutria nigriventer venom (another South American species also belonging to the Ctenidae family), namely $\omega$-phonetoxin IIA and $\omega$-PnTx3-6 (Cassola et al., 1998; Vieira et al., 2005) suggested that CSTX-1 may interact with $\mathrm{Ca}_{\mathrm{v}}$ channels. This prompted us to investigate whether CSTX1 toxicity may be caused by its putative action as an ion channel modulator. Using the wholecell configuration of the patch-clamp technique in cockroach and a variety of rat neurons, we studied the effect of CSTX-1 on currents flowing through various voltage-gated ion channels.

In cockroach neurons, CSTX-1 inhibited $\mathrm{Ba}^{2+}$ currents evoked at $-30 \mathrm{mV}$ as well as $+30 \mathrm{mV}$ with similar potency. This indicates that both M-LVA and $\mathrm{HVA} \mathrm{Ca}_{\mathrm{v}}$ channels are blocked by this toxin in insects. Many spider toxins have evolved as effective blockers of $\mathrm{Ca}_{\mathrm{v}}$ 
channels expressed in prey animals. Considering the differences between insect and mammalian $\mathrm{Ca}_{\mathrm{v}}$ channels (Wicher and Penzlin, 1997, and see below), it is not surprising that several of these spider toxins, namely the $\omega$-atracotoxin- 1 and -2 families, potently block $\mathrm{Ca}^{2+}$ currents in insects, but are ineffective on their mammalian counterpart (Wang et al., 1999; Wang et al., 2001; Tedford et al., 2004b). This phyla selectivity identifies several spider toxins as suitable lead compounds for the development of insecticides (Tedford et al., 2004a). On the other hand some spiders, for example Agelenopsis aperta (Adams, 2004), produce channel blockers that show potent actions in mammals, although animals from this phylum rarely contribute to the spider's prey. In particular, this has been observed in binding and electrophysiological experiments using mammalian vs. insect neurons with the $\delta$-atracotoxin1 family of $\mathrm{Na}_{\mathrm{v}}$ channel modulators from Australian funnel-web spiders (Nicholson et al., 2004). Such toxins cannot be used as biopesticides but may become useful as molecular research tools in cell biology or as leads for drug development, with their therapeutic potential being dependent on ion channel subtype selectivity.

CSTX-1 appears to fall into the latter group of spider toxins, because it not only inhibits $\mathrm{Ca}_{\mathrm{v}}$ channel currents of cockroach neurons but exerted the same effect on rat neurons. However, while in the insect preparation both M-LVA and HVA $\mathrm{Ca}_{\mathrm{v}}$ channels were affected, CSTX-1 only inhibited L-type HVA $\mathrm{Ca}_{\mathrm{v}}$ channel currents in neurons of the rat, leaving all other voltage-gated sodium, potassium and non-L-type $\mathrm{Ca}_{\mathrm{v}}$ channel currents tested unaffected. Therefore we attempted to identify the molecular target of this toxin enabling it to block $\mathrm{Ca}_{\mathrm{v}}$ channels in both invertebrates and vertebrates. To examine this issue we need to reconsider the currents that were blocked by CSTX-1. In SCG neurons, various $\mathrm{Ca}_{\mathrm{v}}$ channel subtypes (L, N-, and R-type) contribute to total $\mathrm{Ca}^{2+}$ currents (Lin et al., 1996). Several studies have shown that while $\mathrm{N}$-type $\mathrm{Ca}^{2+}$ currents predominate, L-type $\mathrm{Ca}^{2+}$ currents contribute by up to $30 \%$ of the total current (Barrett and Rittenhouse, 2000; Liu et al., 2001; Martinez-Pinna et al., 2002). We found similar contributions of these $\mathrm{Ca}_{\mathrm{v}}$ channel subtypes to $I_{\mathrm{Ba}}$ using the N- 
type blocker $\omega$-conotoxin GVIA and the L-type antagonist nitrendipine. CSTX-1 inhibited $I_{\mathrm{Ba}}$ in SCG neurons in a fully reversible manner. The lack of additivity of CSTX-1 and nitrendipine indicates that inhibition of $I_{\mathrm{Ba}}$ is due to a blocking effect of CSTX-1 on L-type $\mathrm{Ca}_{\mathrm{v}}$ channels. Nevertheless, the contribution of L-type $I_{\mathrm{Ba}}$ to total macroscopic $I_{\mathrm{Ba}}$ was variable (15-40\%) among different SCG neurons. Therefore we employed GH3/GH4 cells to further characterise the actions of CSTX-1 on $\mathrm{Ca}_{\mathrm{v}}$ channels because these pituitary cell lines have been previously reported to exhibit a high proportion of L-type $\mathrm{Ca}_{\mathrm{v}}$ channels (Leão et al., 2000). Experiments performed in this study revealed that, on average, $95 \%$ of $\mathrm{HVA} \mathrm{Ca}$ channel currents flow via the dihydropyridine-sensitive L-type $\mathrm{Ca}_{\mathrm{v}}$ channels in $\mathrm{GH} 3$ cells. Barium currents in GH3 cells were inhibited by CSTX-1 in a concentration-dependent and entirely reversible manner, with an $I C_{50}$ of $260 \mathrm{nM}$ and an inhibition of $92 \% \pm 3 \%$ at the highest toxin concentration tested $(1 \mu \mathrm{M})$. In GH4 cells (a clonal isolate of GH3 cells) a saturating effect of CSTX-1 on $I_{\mathrm{Ba}}$ was obtained with concentrations between 30 and $100 \mathrm{nM}$, which blocked $80 \%$ and $77 \%$ of total $I_{\mathrm{Ba}}$, respectively. Using the dihydropyridine nitrendipine, we determined that a similar percentage of total $I_{\mathrm{Ba}}$ flows via L-type $\mathrm{Ca}_{\mathrm{v}}$ channels in this cell line. Therefore, CSTX-1 appears capable of blocking up to $100 \%$ of this $\mathrm{Ca}_{\mathrm{v}}$ channel subtype in GH3 and GH4 cells and can be considered as an effective antagonist of L-type $\mathrm{Ca}_{\mathrm{v}}$ channels. The concentration-response curve established with $\mathrm{GH} 4$ cells appeared to be biphasic. The data could be best fitted using a two-site binding model yielding two $I C_{50}$ values differing by $\sim 1000$-fold. This indicates that two high affinity targets for CSTX-1 are present in GH4 L-type $\mathrm{Ca}_{\mathrm{v}}$ channels. The concentration-response data indicate that L-type $\mathrm{Ca}_{\mathrm{v}}$ channels in $\mathrm{GH} 3$ cells have considerably lower affinity than corresponding channels in GH4 cells. The variation in affinities suggests that several different subtypes of Ltype $\mathrm{Ca}_{\mathrm{v}}$ channels may be affected by CSTX-1.

Native $\mathrm{Ca}_{\mathrm{v}}$ channels are heteromultimers of a pore forming $\alpha_{1}$-subunit and the auxiliary $\alpha_{2} \delta, \beta$ and, in some tissues, $\gamma$ subunits. These are encoded by four genes for $\beta$ - 
subunits $\left(\beta_{1}\right.$ through $\left.\beta_{4}\right)$, four genes for the $\alpha_{2} \delta$ complex $\left(\alpha_{2} \delta-1\right.$ through $\left.\alpha_{2} \delta-4\right)$, and eight genes for the $\gamma$-subunits (Doering and Zamponi, 2003). Available RT-PCR and electrophysiology data on GH3 cells suggest that L-type $I_{\mathrm{Ca}(\mathrm{V})}$ in this cell line are mediated via the $\alpha_{1}$-subunit of $\mathrm{Ca}_{\mathrm{v}} 1.2\left(\alpha_{1 \mathrm{C}}\right)$ and $\mathrm{Ca}_{\mathrm{v}} 1.3\left(\alpha_{1 \mathrm{D}}\right)$, with a predominance of the $\mathrm{Ca}_{\mathrm{v}} 1.3$ subtype that is expressed as several splice variants (Safa et al., 2001). Considering this, the different L-type $\mathrm{Ca}_{\mathrm{v}}$ channel targets suggested by the variation of CSTX-1 affinity in GH4 and GH3 cells may correspond to (i) different $\alpha_{1}$-subunits, e.g. $\mathrm{Ca}_{\mathrm{v}} 1.2$ and $\mathrm{Ca}_{\mathrm{v}} 1.3$, (ii) splice variants of $\mathrm{Ca}_{\mathrm{v}} 1.3$, or (iii) the presence of different isoforms of the various auxiliary subunits in the $\mathrm{Ca}_{\mathrm{v}}$ channel heteromultimer, because the subunit composition has been found to significantly affect the interaction with ligands (Martin et al., 2002; Gurnett et al., 1997; Felix et al., 1997; Mould et al., 2004; Helton et al., 2002). The biphasic nature of the concentrationresponse curve obtained in GH4 cells may be caused by similar variations in channel subunits forming the $\mathrm{Ca}_{\mathrm{v}}$ channel heteromer.

Considering the published channel expression data for GH3 cells, CSTX-1 appears to target vertebrate $\mathrm{Ca}_{\mathrm{v}} 1.2$ and $\mathrm{Ca}_{\mathrm{v}} 1.3$ channels. Our experiments on $\mathrm{Ca}_{\mathrm{v}}$ channels in skeletal muscle cells suggest that this toxin, at least at submicromolar concentrations, does not inhibit $\mathrm{Ca}_{\mathrm{v}} 1.1$ channels, which argues for subtype-selectivity within the L-type family of $\mathrm{Ca}_{\mathrm{v}}$ channels.

In contrast to the apparent target-selectivity of CSTX-1 in rat neurons, the similar degree of current block at $-30 \mathrm{mV}$ (M-LVA currents dominating) and $+30 \mathrm{mV}$ (HVA currents dominating) in DUM neurons indicates that the molecular target of CSTX-1 maybe common to both M-LVA and HVA $\mathrm{Ca}_{\mathrm{v}}$ channels in insects. The conclusion that M-LVA and HVA calcium currents were carried by different calcium channel populations was drawn based on pharmacological differences, such as sensitivity to cone snail and spider toxins (Wicher and Penzlin, 1997). Importantly, inhibition by these toxins often occurs with much slower kinetics than in vertebrate preparations (Wicher and Penzlin, 1997). It should be noted that 
relatively slow association and dissociation kinetics of CSTX-1 on insect neurons as compared to rat neurons were also observed in this study as evidenced by a $\tau_{\mathrm{on}}$ of $33.1 \mathrm{~s}$ for insect DUM neurons vs. a $\tau_{\text {on }}$ value of $3.1 \mathrm{~s}$ for GH3 cells. These observations indicate that $\mathrm{Ca}_{\mathrm{v}}$ channels in cockroach neurons are only distantly related to vertebrate HVA Cav channels. In support of this view, antibodies directed against $\mathrm{N}$ - and P/Q-type $\mathrm{Ca}_{\mathrm{v}}$ channels failed to immunostain membranes of cockroach neurons, although specific peptide toxin blockers of $\mathrm{N}$ - and P/Q-type channels were found capable of inhibiting $I_{\mathrm{Ca}(\mathrm{V})}$ recorded from neurons of this arthropod (Wicher et al., 2001). With regard to L-type channels, $\mathrm{Ca}_{\mathrm{v}}$ channel currents of DUM neurons were reported to show sensitivity to both phenylalkylamines and benzylalkylamines but, unlike vertebrates, not dihydropyridines such as nifedipine (Wicher and Penzlin, 1997). On the other hand, in Drosophila four genes have been reported to encode for the $\alpha_{1}$-subunits of $\mathrm{Ca}_{\mathrm{v}}$ channels based on homology to their mammalian counterparts. DmcalA encodes for N-type $\mathrm{Ca}_{\mathrm{v}}$ channels, DmcalD for L-type, $D m \alpha_{l} G$ for T-type while $D m \alpha_{l} U$ is homologous to two $\mathrm{Ca}_{\mathrm{v}}$ channel genes of C. elegans (Littleton and Ganetzky, 2000). DmcalD is expressed in Drosophila muscle and throughout the nervous system, where alternative splicing causes substantial channel heterogeneity (Zheng et al., 1995; Ren et al., 1998). This gene is considered a candidate for encoding the phenylalkylamine-sensitive, dihydropyridine-insensitive $\mathrm{Ca}_{\mathrm{v}}$ channel in Drosophila brain membranes (Zheng et al., 1995). Moreover, the Dmca1D $\mathrm{Ca}_{\mathrm{v}}$ channel is thought to carry the dihydropyridine- and phenylalkylamine-sensitive $\mathrm{Ca}^{2+}$ current underlying action potentials in Drosophila muscle cells (Littleton and Ganetzky, 2000). In support of this suggestion, mutations in DmcalD cause defects in muscle $\mathrm{Ca}^{2+}$ currents (Eberl et al., 1998). Thus, Dmca1D provides a perfect target for a spider toxin, since its blockade would cause muscular paralysis. The $78 \%$ sequence similarity between Dmca1D and rat brain $\mathrm{Ca}_{\mathrm{v}} 1.3\left(\alpha_{1 \mathrm{D}}\right)$ and the observation that Drosophila muscle HVA $\mathrm{Ca}^{2+}$ currents are sensitive to both phenylalkylamines and dihydropyridines (Gielow et al., 1995; Zheng et al., 1995; Morales et al., 1999) indicate that 
Drosophila skeletal muscle $\mathrm{Ca}_{\mathrm{v}}$ channels strongly resemble vertebrate L-type $\mathrm{Ca}_{\mathrm{v}}$ channels. A similar situation may hold true for other insect species, because binding sites for both phenylalkylamines and dihydropyridines were identified in Periplaneta muscle cells but not in the nervous system, where only phenylalkylamines binding sites were found (Skeer and Sattelle, 1993). We therefore suggest that CSTX-1 has evolved as a blocker of muscle 'Ltype-like' $\mathrm{Ca}_{\mathrm{v}}$ channels in insects to assist the spider in capturing insect prey. Similarities between this channel and certain mammalian L-type channels of the $\mathrm{Ca}_{\mathrm{v}} 1.3$ subfamily may explain the toxicity of CSTX-1 in rodent species. In support of this hypothesis, GH3 and GH4 cells preferentially express $\mathrm{Ca}_{\mathrm{v}} 1.3 \alpha_{1}$-subunits, and dihydropyridine-sensitive $I_{\mathrm{Ca}(\mathrm{V})}$ in $\mathrm{SCG}$ neurons are mediated by $\mathrm{Ca}_{\mathrm{v}} 1.3$, rather than $\mathrm{Ca}_{\mathrm{v}} 1.2, \alpha_{1}$-subunits (Lin et al., 1996). However, the degree of homology between L-type-like insect $\mathrm{Ca}_{\mathrm{v}}$ channels and mammalian $\mathrm{Ca}_{\mathrm{v}}$ channels of the $\mathrm{Ca}_{\mathrm{v}} 1.3$ family varies among insect species. Using the ClustalW alignment program (European Informatics Institute) we found sequence identities of 47 to $66 \%$ between rodent $\mathrm{Ca}_{\mathrm{v}} 1.3 \alpha_{1}$-subunits and $\alpha_{1}$-subunits of dipteran insects. This diversity may explain the differences in the susceptibility of various insect species to $C$. salei venom described previously (Kuhn-Nentwig et al., 1998). Flies, such as Drosophila and Protophormia spp. are the most sensitive arthropod species to $C$. salei venom $\left(L D_{50}\right.$ of $\left.<0.02 \mathrm{nl} / \mathrm{mg}\right)$, whereas the $L D_{50}$ of $C$. salei venom in Periplaneta americana was $10 \mathrm{nl} / \mathrm{mg}^{-}$(Wullschleger \& Nentwig, 2002) some 10,000 -fold less than in mice. This is borne out by the $\sim 1000$-fold reduction in $I C_{50}$ values for CSTX-1 on rat GH4 cells compared to P. americana DUM neurons.

In conclusion, we postulate that a $\mathrm{Ca}_{\mathrm{v}}$ channel heteromultimer containing an L-type pore-forming $\alpha_{1}$-subunit is the most probable candidate for the molecular target of CSTX-1, especially given the potency in GH4 cells. Further experiments using heterologous expression of different combinations of L-type $\alpha_{1}$ - and auxiliary $\mathrm{Ca}_{\mathrm{v}}$ channel subunits will be needed to unambiguously identify the high affinity molecular target of CSTX-1. Moreover, CSTX-1 appears to discriminate between channel subtypes within the L-type family of $\mathrm{Ca}_{\mathrm{v}}$ channels in 
terms of potency of channel block. Other voltage-gated ion channels appear to be insensitive to CSTX-1, including $\mathrm{K}_{\mathrm{v}}$ and $\mathrm{Na}_{\mathrm{v}}$ channels as well as $\mathrm{N}$-type and $\mathrm{P} / \mathrm{Q}$ type $\mathrm{Ca}_{\mathrm{v}}$ channels, which are likely to be responsible for the non-L-type $I_{\mathrm{Ba}}$ in GH3/GH4 cells (Safa et al., 2001). Therefore our findings provide evidence that CSTX-1 may become a useful molecular tool that allows dissection of the functional role of various L-type $\mathrm{Ca}_{\mathrm{v}}$ channel subtypes in cell biology.

\section{Acknowledgements}

We thank Thomas Weiger and Karlheinz Hilber for providing GH4 and C2C12 cells, respectively, Urs Kämpfer for amino acid composition and N-terminal sequencing and Johann Schaller for ESI-MS measurement of CSTX-1 (Analytical Research and Services, Department of Chemistry and Biochemistry, University of Bern). This work was supported by grants from the Austrian Science Fund (FWF; P15797) to Stefan Boehm, the Swiss National Science Foundation to Wolfgang Nentwig, the Australian Research Council to Graham Nicholson and by the Brazilian Research Council (CNPq) and FAPEMIG to Paulo Beirão and Jader Cruz.

\section{References}

Adams, M. E., 2004. Agatoxins: ion channel specific toxins from the American funnel web spider, Agelenopsis aperta. Toxicon 43, 509-525.

Bailey, P., Wilce, J. A., 2001. Venom as a source of useful biologically active molecules. Emerg. Med. Australas. 13, 28-36. 
Barrett, C. F., Rittenhouse, A. R., 2000. Modulation of N-type calcium channel activity by Gproteins and protein kinase C. J. Gen. Physiol. 115, 277-286.

Bogin, O., 2005. Venom peptides and their mimetics as potential drugs. Modulator 19, 14-20.

Bourinet, E., Mangoni, M. E., Nargeot, J., 2004. Dissecting the functional role of different isoforms of the L-type $\mathrm{Ca}^{2+}$ channel. J. Clin. Invest. 113, 1382-1384.

Cassola, A. C., Jaffe, H., Fales, H. M., Castro Afeche, S., Magnoli, F., Cipolla-Neto, J., 1998. $\omega$-Phonetoxin-IIA: a calcium channel blocker from the spider Phoneutria nigriventer. Pflügers Archiv (Eur. J. Physiol.) 436, 545-552.

Catterall, W. A., Striessnig, J., Snutch, T. P., Perez-Reyes, E., 2003. International Union of Pharmacology. XL. Compendium of voltage-gated ion channels: calcium channels. Pharmacol. Rev. 55, 579-581.

Doering, C. J., Zamponi, G. W., 2003. Molecular pharmacology of high voltage-activated calcium channels. J. Bioenerg. Biomembr. 35, 491-505.

Eberl, D. F., Ren, D., Feng, G., Lorenz, L. J., Van Vactor, D., Hall, L. M., 1998. Genetic and developmental characterization of Dmca1D, a calcium channel alpha1 subunit gene in Drosophila melanogaster. Genetics 148, 1159-1169.

Felix, R., Gurnett, C. A., De Waard, M., Campbell, K. P., 1997. Dissection of functional domains of the voltage-dependent $\mathrm{Ca}^{2+}$ channel $\alpha_{2} \delta$ subunit. J. Neurosci. 17, 68846891.

Gielow, M. L., Gu, G. G., Singh, S., 1995. Resolution and pharmacological analysis of the voltage-dependent calcium channels of Drosophila larval muscles. J. Neurosci. 15, 6085-6093.

Glassmeier, G., Hauber, M., Wulfsen, I., Weinsberg, F., Bauer, C. K., Schwarz, J. R., 2001. $\mathrm{Ca}^{2+}$ channels in clonal rat anterior pituitary cells (GH3/B6). Pflügers Archiv (Eur. J. Physiol.) 442, 577-587. 
Grolleau, F., Lapied, B., 1996. Two distinct low-voltage-activated $\mathrm{Ca}^{2+}$ currents contribute to the pacemaker mechanism in cockroach dorsal unpaired median neurons. J. Neurophysiol. 76, 963-976.

Gurnett, C. A., Felix, R., Campbell, K. P., 1997. Extracellular interaction of the voltagedependent $\mathrm{Ca}^{2+}$ channel $\alpha_{2} \delta$ and $\alpha_{1}$ subunits. J. Biol. Chem. 272, 18508-18512.

Harvey, A. L., 2002. Toxins 'R' Us: more pharmacological tools from nature's superstore. Trends Pharmacol. Sci. 23, 201-203.

Helton, T. D., Kojetin, D. J., Cavanagh, J., Horne, W. A., 2002. Alternative splicing of a $\beta_{4}$ subunit proline-rich motif regulates voltage-dependent gating and toxin block of $\mathrm{Ca}_{\mathrm{v}} 2.1$ $\mathrm{Ca}^{2+}$ channels. J. Neurosci. 22, 9331-9339.

Kepplinger, K. J., Forstner, G., Kahr, H., Leitner, K., Pammer, P., Groschner, K., Soldatov, N. M., Romanin, C., 2000. Molecular determinant for run-down of L-type $\mathrm{Ca}^{2+}$ channels localized in the carboxyl terminus of the $\alpha_{1 \mathrm{C}}$ subunit. J. Physiol. 529, 119-130.

Kubista, H., Mafra, R. A., Chong, Y., Nicholson, G. M., Beirao P. S., Cruz, J. S., Boehm, S., Nentwig, W., Kuhn-Nentwig, L., 2006. CSTX-1, a neurotoxin from the venom of the hunting spider Cupiennius salei, is a selective blocker of L-type calcium channels in rat neurons. FENS Abstr. Vol. 3, A084.16.

Kuhn-Nentwig, L., Schaller, J., Nentwig W., 1994. Purification of toxic peptides and the amino acid sequence of CSTX-1 from the multicomponent venom of Cupiennius salei (Araneae: Ctenidae). Toxicon 32, 287-302.

Kuhn-Nentwig, L., Bücheler, A., Studer, A., Nentwig, W., 1998. Taurine and histamine: low molecular compounds in prey hemolymph increase the killing power of spider venom. Naturwissenschaften $85,136-138$.

Kuhn-Nentwig, L., Müller, J., Schaller, J., Walz, A., Dathe, M., Nentwig, W., 2002. Cupiennin 1, a new family of highly basic antimicrobial peptides in the venom of the spider Cupiennius salei (Ctenidae). J. Biol. Chem. 277, 11208-11216. 
Kuhn-Nentwig, L., Schaller, J., Nentwig W., 2004. Biochemistry, toxicology and ecology of the venom of the spider Cupiennius salei (Ctenidae). Toxicon 43, 543-553.

Leão, R. M., Cruz, J. S., Diniz, C. R., Cordeiro, M. N., Beirão, P. S. L., 2000. Inhibition of neuronal high-voltage activated calcium channels by the $\omega$-Phoneutria nigriventer Tx33 peptide toxin. Neuropharmacology 39, 1756-1767.

Lechner, S. G., Mayer, M., Boehm, S., 2003. Activation of M1 muscarinic receptors triggers transmitter release from rat sympathetic neurons through an inhibition of M-type $\mathrm{K}^{+}$ channels. J. Physiol. 553, 789-802.

Lievano, A., Bolden, A., Horn, R., 1994. Calcium channels in excitable cells: divergent genotypic and phenotypic expression of $\alpha_{1}$-subunits. Am. J. Physiol. 267, C411-C424.

Lin, Z., Harris, C. \& Lipscombe, D., 1996. The molecular identity of Ca channel alpha 1subunits expressed in rat sympathetic neurons. J. Mol. Neurosci. 7, 257-267.

Littleton, J. T., Ganetzky, B., 2000. Ion channels and synaptic organization: analysis of the Drosophila genome. Neuron 26, 35-43.

Liu, L., Barrett, C. F., Rittenhouse, A. R., 2001. Arachidonic acid both inhibits and enhances whole cell calcium currents in rat sympathetic neurons. Am. J. Physiol. Cell. Physiol. 280, C1293-C1305.

Martin, D. J., McClelland, D., Herd, M. B., Sutton, K. G., Hall, M. D., Lee, K., Pinnock, R. D., Scott, R. H., 2002. Gabapentin-mediated inhibition of voltage-activated $\mathrm{Ca}^{2+}$ channel currents in cultured sensory neurones is dependent on culture conditions and channel subunit expression. Neuropharmacology 42, 353-366.

Martinez-Pinna, J., Lamas, J. A., Gallego, R., 2002. Calcium current components in intact and dissociated adult mouse sympathetic neurons. Brain Res. 951, 227-236.

Morales, M., Ferrus, A., Martinez-Padron, M., 1999. Presynaptic calcium-channel currents in normal and csp mutant Drosophila peptidergic terminals. Eur. J. Neurosci. 11, 18181826. 
Mouhat, S., Jouirou, B., Mosbah, A., De Waard, M., Sabatier, J-M., 2004. Diversity of folds in animal toxins acting on ion channels. Biochem. J. 378, 717-726.

Mould, J., Yasuda, T., Schroeder, C. I., Beedle, A. M., Doering, C. J., Zamponi, G. W., Adams, D. J., Lewis, R. J., 2004. The $\alpha_{2} \delta$ auxiliary subunit reduces affinity of $\omega-$ conotoxins for recombinant N-type $\left(\mathrm{Ca}_{\mathrm{v}} 2.2\right)$ calcium channels. J. Biol. Chem. 279, $34705-34714$.

Nicholson, G. M., 2006. Spider venom peptides. In: Kastin A., (Ed), The Handbook of Biologically Active Peptides. Elsevier, San Diego, in press.

Nicholson, G. M., Little, M. J., Birinyi-Strachan, L. C., 2004. Structure and function of $\delta$ atracotoxins: lethal neurotoxins targeting the voltage-gated sodium channel. Toxicon $43,587-599$.

Norton, R. S., Pallaghy, P. K., 1998. The cystine knot structure of ion channel toxins and related polypeptides. Toxicon $36,1573-1583$.

Pukala, T. L., Doyle, J. R., Llewellyn, L. E., Kuhn-Nentwig L., Separovic, F., Bowie, J. H., 2007. Cupiennin 1a, an antimicrobial peptide from the venom of the neotropical wandering spider Cupiennius salei, also inhibits the formation of nitric oxide by neuronal nitric oxide synthase. FEBS J. (in press).

Ren, D., Xu, H., Eberl, D. F., Chopra, M., Hall, L. M., 1998. A mutation affecting dihydropyridine-sensitive current levels and activation kinetics in Drosophila muscle and mammalian heart calcium channels. J Neurosci. 18, 2335-2341.

Safa, P., Boulter, J., Hales, T. G., 2001. Functional properties of $\mathrm{Ca}_{\mathrm{v}} 1.3$ (alpha1D) L-type $\mathrm{Ca}^{2+}$ channel splice variants expressed by rat brain and neuroendocrine GH3 cells. J. Biol. Chem. 276, 38727-38737.

Sinakevitch, I. G., Geffard, M., Pelhate, M., Lapied, B., 1996. Anatomy and targets of dorsal unpaired median neurones in the terminal abdominal ganglion of the male cockroach Periplaneta americana L. J. Comp. Neurol. 367, 147-163. 
Skeer, J. M., Sattelle, D. B., 1993. Characterization of phenylalkylamine binding sites in insect (Periplaneta americana) nervous system and skeletal muscle membranes. Arch. Insect Biochem. Physiol. 23, 111-124.

Soldatov, N. M., 2003. $\mathrm{Ca}^{2+}$ channel moving tail: link between $\mathrm{Ca}^{2+}$-induced inactivation and $\mathrm{Ca}^{2+}$ signal transduction. Trends Pharmacol. Sci. 24, 167-171.

Tedford, H. W., Sollod, B. L., Maggio, F., King, G. F., 2004a. Australian funnel-web spiders: master insecticide chemists. Toxicon 43, 601-618.

Tedford, H. W., Gilles, N., Menez, A., Doering, C. J., Zamponi, G. W., King, G.F., 2004b. Scanning mutagenesis of omega-atracotoxin-Hvla reveals a spatially restricted epitope that confers selective activity against insect calcium channels. J. Biol. Chem. 279, 44133-44140.

Vartian, N., Boehm, S., 2001. P2Y receptor-mediated inhibition of voltage-activated $\mathrm{Ca}^{2+}$ currents in PC12 cells. Eur. J. Neurosci. 13, 899-908.

Vieira, L. B., Kushmerick, C., Hildebrand, M. E., Garcia, E., Stea, A., Cordeiro, M. N., Richardson, M., Gomez, M. V., Snutch, T. P., 2005. Inhibition of high voltage-activated calcium channels by spider toxin PnTx3-6. J. Pharmacol. Exp. Ther. 314, 1370-1377.

Wang, X., Smith, R., Fletcher, J. I., Wilson, H., Wood, C. J., Howden, M. E., King, G. F., 1999. Structure-function studies of omega-atracotoxin, a potent antagonist of insect voltage-gated calcium channels. Eur. J. Biochem. 264, 488-494.

Wang, X. H., Connor, M., Wilson, D., Wilson, H. I., Nicholson, G. M., Smith, R., Shaw, D., Mackay, J. P., Alewood, P. F., Christie, M. J., King, G. F., 2001. Discovery and structure of a potent and highly specific blocker of insect calcium channels. J. Biol. Chem. 276, 40306-40312.

Wicher, D., Penzlin, H., 1994. $\mathrm{Ca}^{2+}$ currents in cockroach neurones: properties and modulation by neurohormone D. Neuroreport 5, 1023-1026. 
Wicher, D., Penzlin, H., 1997. $\mathrm{Ca}^{2+}$ currents in central insect neurons: electrophysiological and pharmacological properties. J. Neurophysiol. 77, 186-199.

Wicher, D., Walther, C., Wicher, C., 2001. Non-synaptic ion channels in insects-basic properties of currents and their modulation in neurons and skeletal muscles. Prog. Neurobiol. 64, 431-525.

Wullschleger, B., Nentwig, W., 2002. Influence of venom availability on a spider's preychoice behaviour. Funct. Ecol. 16, 802-807.

Wullschleger, B., Nentwig, W., Kuhn-Nentwig, L., 2005. Spider venom: enhancement of venom efficacy mediated by different synergistic strategies in Cupiennius salei. J. Exp. Biol. 208, 2115-2121.

Zebedin, E., Sandtner, W., Galler, S., Szendroedi, J., Just, H., Todt, H., Hilber. K., 2004. Fiber type conversion alters inactivation of voltage-dependent sodium currents in murine C2C12 skeletal muscle cells. Am. J. Physiol. Cell Physiol. 287, C270-C280.

Zeilhofer, H. U., Blank, N. M., Neuhuber, W. L., Swandulla, D., 2000. Calcium-dependent inactivation of neuronal calcium channel currents is independent of calcineurin. Neuroscience 95, 235-241.

Zheng, W., Feng, G., Ren, D., Eberl, D. F., Hannan, F., Dubald, M., Hall, L. M., 1995. Cloning and characterization of a calcium channel alpha 1 subunit from Drosophila melanogaster with similarity to the rat brain type D isoform. J. Neurosci. 15, 11321143. 


\section{Legends}

Figure 1 Purification and primary structure of CSTX-1. Purity control of CSTX-1 $(10 \mu \mathrm{g})$ isolated from the venom of Cupiennius salei by RP-HPLC on an Atlantis $\mathrm{dC}_{18} 3 \mu \mathrm{m}$ column (3.9 $\times 150 \mathrm{~mm}$, Waters) under isocratic conditions $(0.1 \% \mathrm{v} / \mathrm{v}$ TFA in $32 \%$ acetonitrile, Retention time [RT] $9.07 \mathrm{~min}$ ). For complete details of isolation see the methods. The disulfide-bridge pattern for the cysteine residues (boxed in black) are indicated above the sequences as well as the positive charge, especially of the C-terminus of the peptide.

Figure 2 Concentration-dependent block of $\mathrm{Ca}_{\mathrm{v}}$ channels in cockroach DUM neurons by CSTX-1. Whole-cell $I_{\mathrm{Ba}}$ were evoked by $100-\mathrm{ms}$ depolarising test pulses from a holding potential of $-90 \mathrm{mV}$ to $-30 \mathrm{mV}$ (left-hand panels) and $+30 \mathrm{mV}$ (right-hand panels) respectively, in the absence, and presence, of CSTX-1. Panels show effects following a 10min perfusion with $100 \mathrm{nM}(\mathrm{A}, \mathrm{B}), 300 \mathrm{nM}(\mathrm{C}, \mathrm{D})$ and $900 \mathrm{nM} \mathrm{CSTX}-1$ (E, F). Washout with toxin-free solution did not significantly reverse these effects. $(G, H)$ Concentration-response curves for the inhibition of peak $I_{\mathrm{Ba}}$ by CSTX-1 at $-30 \mathrm{mV}(\mathrm{G})$ and $+30 \mathrm{mV}(\mathrm{H})$. Data were fitted with Eq. 1 in the Methods section. Numbers in brackets above each data point represent the number of experiments performed at that concentration.

Figure 3 Effects of CSTX-1 on the voltage-dependence of $\mathrm{Ca}_{\mathrm{v}}$ channel activation in cockroach DUM neurons. Families of $I_{\mathrm{Ba}}$ were elicited by depolarising test pulses to $+40 \mathrm{mV}$ from a holding potential of $-90 \mathrm{mV}$ in $10-\mathrm{mV}$ steps. Data shown represents superimposed current traces recorded before (A), and after (B), a 10-min perfusion with $300 \mathrm{nM}$ CSTX-1. (C), Peak $I_{\mathrm{Ba}}-V$ relationship showing $I_{\mathrm{Ba}}$ recorded before (closed circles), and after (open circles), application of $300 \mathrm{nM} \mathrm{CSTX-1}(n=3)$. Data were fitted with Eq. 3 in the Materials and Methods section. (D) Voltage-independent block by CSTX-1. Percentage inhibition of 
peak $I_{\mathrm{Ba}}$ by $100 \mathrm{nM}$ (closed circles) and $300 \mathrm{nM}$ (open circles) CSTX-1 at different depolarising test pulses $(n=3)$.

Figure 4 CSTX-1 blocks L-type $\mathrm{Ba}^{2+}$ currents in SCG neurons. $I_{\mathrm{Ba}}$ were elicited by $30-\mathrm{ms}$ voltage steps from a holding potential of $-80 \mathrm{mV}$ to $0 \mathrm{mV}$. Currents are shown normalised to their respective control currents. (A) Current traces recorded before (control), during and after (wash) application of $1 \mu \mathrm{M}$ CSTX-1. (B) Current traces recorded from the same neuron as in $\mathrm{A}$ in the presence of $1 \mu \mathrm{M}$ nitrendipine and after the subsequent addition of $1 \mu \mathrm{M}$ CSTX-1. In this neuron CSTX-1 blocked $I_{\mathrm{Ba}}$ by $33 \%$ (A) but did not further reduce the current in the presence of nitrendipine (B). (C) and (D) Currents recorded under control conditions, after addition of $1 \mu \mathrm{M} \omega$-conotoxin GVIA (GVIA), after subsequent addition of $1 \mu \mathrm{M}$ CSTX-1 and after washout of toxins (wash). Note that block by $\omega$-conotoxin GVIA is irreversible. The current recorded in the presence of $0.5 \mathrm{mM} \mathrm{Cd}^{2+}$ is also shown $\left(\mathrm{Cd}^{2+}\right)$. In the experiment shown in $(\mathrm{C})$, the conotoxin blocked $I_{\mathrm{Ba}}$ by $50 \%$. CSTX-1 blocked $28 \%$ of the remaining nonN-type current, which equals $14 \%$ of total $I_{\mathrm{Ba}} .36 \%$ of total $I_{\mathrm{Ba}}$ in this neurone were insensitive to conotoxin and CSTX-1. In the experiment shown in (D), $41 \%$ percent of $I_{\mathrm{Ba}}$ was blocked by the conotoxin, CSTX-1 inhibited the remaining current by $68 \%$, which equals $40 \%$ of total $I_{\mathrm{Ba}}$ recorded in the absence of toxins. In (C) and (D) the current traces are shown truncated at the time where the voltage returned to the holding potential.

Figure 5 CSTX-1 inhibits $\mathrm{Ba}^{2+}$ currents in GH3 cells in a voltage-independent manner. Currents were induced in $\mathrm{GH} 3$ cells, voltage-clamped to $-80 \mathrm{mV}$, by $50-\mathrm{ms}$ voltage steps to 0 $\mathrm{mV}$ at a stimulation frequency of $0.2 \mathrm{~Hz}$. (A) Plot of current density (pA/pF) determined before, during and after application of $1 \mu \mathrm{M}$ CSTX-1. (B) Sample traces of $I_{\mathrm{Ba}}$ from the experiment shown in (A). (C) Time course of inhibition: $I_{\mathrm{Ba}}$ recorded before $(50 \mathrm{~s})$ and after 
addition of $1 \mu \mathrm{M}$ CSTX-1. Peak $I_{\mathrm{Ba}}$ amplitudes in the presence of the toxin were normalised to control peak $I_{\mathrm{Ba}}$. The rate to inhibition is described by a single exponential function with a time constant $\left(\tau_{\text {on }}\right)$ of 3.1 s. Data represent the mean of 5 independent experiments. (D) Current-voltage curves for peak $I_{\mathrm{Ba}}$ elicited by 50 -ms voltage steps from a holding potential of $-80 \mathrm{mV}$ to a series of depolarised potentials under control conditions (open circles) and in the presence of $1 \mu \mathrm{M} \mathrm{CSTX-1} \mathrm{(closed} \mathrm{circles).} \mathrm{Data} \mathrm{represent} \mathrm{the} \mathrm{mean} \mathrm{of} 3$ independent experiments. (E) Evaluation of current inhibition at various depolarised potentials from the current-voltage relation shown in (D).

Figure 6 CSTX-1 inhibits $\mathrm{Ba}^{2+}$ currents in GH3 cells in a concentration-dependent manner. (A) Representative superimposed $I_{\mathrm{Ba}}$ traces obtained in the absence (control) and presence of $30 \mathrm{nM}$ and $300 \mathrm{nM} \mathrm{CSTX-1.} \mathrm{(B)} \mathrm{Concentration-response} \mathrm{relationship} \mathrm{for} \mathrm{the} \mathrm{inhibition} \mathrm{of}$ peak $I_{\mathrm{Ba}}$ by CSTX-1.

Figure 7 CSTX-1 blocks $\mathrm{Ba}^{2+}$ currents in GH4 cells in a concentration-dependent and reversible manner. (A) $\mathrm{Ba}^{2+}$ currents activated by 30-ms voltage steps from a holding potential of $-80 \mathrm{mV}$ to $0 \mathrm{mV}$ in the absence (control), presence of the indicated concentration of CSTX-1 and after washout of the toxin (wash). (B) Concentration-response curve for the inhibition of peak $I_{\mathrm{Ba}}$ by CSTX-1. The curve was fitted to the data using a two-site binding model (see Eq. 2 in the Methods). (C) $\mathrm{Ba}^{2+}$ currents evoked by $30-\mathrm{ms}$ voltage steps as in (A) in the absence, and presence (*), of the indicated concentration of CSTX-1. (D) Superimposed traces of $I_{\mathrm{Ba}}$ evoked as in (A) in the absence (control) or the presence of the indicated concentrations of CSTX-1. All currents are shown normalised to the current obtained under control conditions. 
Figure $8 \mathrm{Ba}^{2+}$ currents in GH4 cells are via L-type $\mathrm{Ca}_{\mathrm{v}}$ channels. (A) $\mathrm{Ba}^{2+}$ currents induced in GH4 cells by $100-\mathrm{ms}$ voltage steps from a holding potential of $-80 \mathrm{mV}$ to $0 \mathrm{mV}$ in the absence (control) and presence of 0.1 to $10 \mu \mathrm{M}$ nitrendipine, as well as after washout of the dihydropyridine (wash). (B) Concentration-response curve for the inhibition of peak $I_{\mathrm{Ba}}$ by nitrendipine derived from experiments ( $n=5$ to 9 for each concentration) carried out under the same conditions as shown in panel (A).

Figure 9 CSTX-1 neither inhibits T-type nor skeletal muscle L-type $\mathrm{Ca}_{\mathrm{v}}$ channels. (A) Current-voltage relation from a DRG neuron of peak $\mathrm{Ca}_{\mathrm{v}}$ channel currents evoked by $100-\mathrm{ms}$ voltage steps from a holding potential of $-100 \mathrm{mV}$ to a range of potentials between $-70 \mathrm{mV}$ and $+45 \mathrm{mV}$. (B) Superimposed currents from the current-voltage relation shown in (A) recorded at $-55 \mathrm{mV},-45 \mathrm{mV},-35 \mathrm{mV},-25 \mathrm{mV}$ and at $-5 \mathrm{mV},+5 \mathrm{mV}$ as well as $+15 \mathrm{mV}$. (LVA) and (HVA) in (A) and (B) denote transient LVA and sustained HVA $I_{\mathrm{Ba}}$, respectively. The arrow in (A) indicates the test potential at which CSTX-1 was studied on LVA (T-type) $\mathrm{Ca}_{\mathrm{v}}$ channel currents. (C) Superimposition of T-type $I_{\mathrm{Ba}}$ elicited in DRG neurons from a holding potential of $-100 \mathrm{mV}$ by $100-\mathrm{ms}$ voltage steps to $-40 \mathrm{mV}$ before, and $60 \mathrm{sec}$ after, application of $100 \mathrm{nM} \mathrm{CSTX-1,} \mathrm{as} \mathrm{indicated.} \mathrm{(D)} \mathrm{Superimposed} I_{\mathrm{Ba}}$ elicited in C2C12 myoballs from a holding potential of $-80 \mathrm{mV}$ by 100 -ms voltage steps to $+20 \mathrm{mV}$ before and $60 \mathrm{sec}$ after application of $100 \mathrm{nM}$ CSTX-1. Note that the fast current transients that occur at the beginning and at the end of the voltage pulse are shown truncated.

Figure 10 CSTX-1 does not modulate outward potassium or inward sodium currents. (A) Outward $I_{\mathrm{K}(\mathrm{V})}$ were evoked in GH4 cells by 150 -ms voltage steps from a holding potential of $-80 \mathrm{mV}$ to $+120 \mathrm{mV}$. The traces show currents recorded before (control) and after addition of $100 \mathrm{nM}$ CSTX-1, as well as in the presence of $20 \mathrm{mM}$ TEA. (B) Inward $I_{\mathrm{Na}(\mathrm{V})}$ were evoked in 
SCG neurons by $30-\mathrm{ms}$ voltage steps to $-10 \mathrm{mV}$ from a holding potential of $-80 \mathrm{mV}$. The superimposed traces show currents recorded before (control), and after addition, of $100 \mathrm{nM}$ CSTX-1, as well as after the addition of $0.5 \mu \mathrm{M}$ TTX. The total overlap of the current trace recorded in the presence of CSTX-1 with the control current trace illustrates that neither amplitude nor inactivation kinetics are affected by the toxin. For clarity, parts of the control current and the current recorded during CSTX-1 application are also shown separately (shifted by $5 \mathrm{~ms}$ ) and on an expanded time-scale (including the first $5 \mathrm{~ms}$ of the evoked current). 